\title{
The Six Faces of Traditional Ecological Knowledge: Challenges and Opportunities for Canadian Co-Management Arrangements
}

\author{
Nicolas Houde $^{l}$
}

\begin{abstract}
The First Nations of Canada have been active over the past three decades in negotiating natural resources co-management arrangements that would give them greater involvement in decisionmaking processes that are closer to their values and worldviews. These values and worldviews are part of the traditional ecological knowledge (TEK) that First Nations possess about the land; to reach agreements to the satisfaction of First Nations, appropriate ways to involve TEK in decision-making processes must be designed. Through a review of the literature on TEK, I identified six "faces" of TEK, i.e., factual observations, management systems, past and current land uses, ethics and values, culture and identity, and cosmology, as well as the particular challenges and opportunities that each face poses to the co-management of natural resources.
\end{abstract}

Key Words: Canada; co-management; co-management arrangement; First Nation; natural resource management; traditional ecological knowledge

\section{INTRODUCTION}

Centralized, bureaucratic resource management systems have been criticized for leading to ecological collapses and for failing to improve people's lives (Agrawal 1995, 2003, Holling and Meffe 1996, Scott 1998, Schelhas et al. 2001). Consequently, attention has started to focus on collaborative processes, which are viewed by many as able: to enhance the robustness of ecological management decisions by gaining access to systems of knowledge and management practices that are better attuned to local specifics (Berkes 1998, Pálsson 1998); to increase the efficiency of decision implementation by involving people that are directly affected by the decisions in activities such as monitoring (Kearney 1989, Pinkerton 1989, Hanna 1998, Sheppard and Meitner 2005); and to increase equity in the decision-making process by moving away from management models that are controlled by a central state that is remote from the needs of local people and from regional and cultural specificities (McCay 1996, Persoon and van Est 2003, Pagdee et al. 2006).

To meet similar goals, Canadian First Nations have been active since the 1970 s in negotiating with the
Canadian state government co-management arrangements that would increase their participation in decisions concerning the land and natural resources. These negotiations, the fruit of years of aboriginal political activism and successive court decisions made in First Nations' favor, have transformed and continue to transform the way in which resource management is undertaken in various Canadian provinces (Coates 1992). Through the 1973 Calder decision, involving the Nisga'a nation of British Columbia, the Supreme Court of Canada recognized the existence of an aboriginal title to the land (Dupuis 2001), thereby pushing the Canadian government to establish the Office of Native Claims to negotiate land claims settlements with several First Nations (Cassidy 1992). A court action launched in the early 1970s by the Cree Nation of Québec led to the conclusion of the first Canadian modern treaty, the James Bay and Northern Québec Agreement, which led to the emergence of co-management boards. The 1990 Sparrow decision acknowledged the ancestral right of Aboriginals to subsistence fishing, and the 1997 Delgamuukw decision gave more authority to oral traditions and narratives in decision-making processes. More recently, other decisions such as Haida vs. BC and Taku River First Nation vs. BC, 
both reached in 2004, gave more leverage to the First Nations' case with regard to increasing their role in strategic planning and natural resources policy making.

From treaties to more informal arrangements, comanagement "broadly refers to the sharing of power and responsibility between government and local resource users, [this being achieved through] various levels of integration of local and state level management systems" (Notzke 1995:187). Through such rearrangement of decision-making processes, First Nations not only seek greater control over land and resources, but aim for processes that will lead to management decisions that are closer to their values and worldviews, reflecting to a wider extent the traditional ecological knowledge (TEK) that they possess about the land. Recent treaties (e.g., Government of Canada 2002, 2005) or bilateral agreements (e.g., Government of Québec and Crees of Québec 2002) therefore often include mechanisms to involve TEK.

However, this task of involving TEK in decisionmaking processes meets with challenges that have much to do with the way that this knowledge is understood. Often, schemes to involve First Nations in decision-making processes have been criticized for equating TEK to a collection of data about the environment that could complement and be integrated within the existing data sets used by state management systems and for failing to acknowledge the value system and cosmological context within which this traditional knowledge was generated and makes sense (e.g., McGregor 1999, 2000, Simpson 2001, Gallagher 2003). Starting with the premise that TEK is more than a mere collection of data about the environment, I review the different faces that have been given to TEK in the literature. I also identify the challenges and opportunities that each one of these faces poses for the design of comanagement arrangements, citing examples from various existing arrangements. The literature on TEK is very broad, and I do not intend to undertake a complete review of the field, if such an endeavor were indeed possible. Rather, for the purposes of this discourse, I focus on how ideas about TEK emerged in the Canadian context of comanagement.

\section{WHAT IS TRADITIONAL ECOLOGICAL KNOWLEDGE?}

I first encountered traditional ecological knowledge (TEK) in the format of a database. I had recently been hired as a policy advisor by a First Nation tribal council in the province of Québec, Canada, and my first task was to create an inventory of geographic information that the council possessed in various forms. Through this work, I discovered a set of ArcView shapefiles bearing the prefix TEK. Not knowing the meaning of these three letters, I asked my colleagues for a meaning and discovered that TEK stood for traditional ecological knowledge. I thought it was curious that an English acronym would be used to name the files, considering that hardly any of my colleagues were proficient in the English language. Even stranger was the juxtaposition of TEK with French abbreviations, creating file names such as tekcas (for castor: the beaver) or tekfbro (for frayère à brochet: pike spawning bed). As I eventually realized, "les TEKs" (the TEKs), sometimes called "les milieux de vies" (habitats) in French, stood for discrete entities, i.e., polygons identifiable on maps, as sites of significance to be protected from logging operations. For me, the thought that a milieu de vie could be reduced to a digitized polygon and swapped between the tribal council and forest companies or among forest companies was very strange. Nevertheless, it seemed that in the region in which I worked and in much of the literature with which I was becoming familiar, TEK was largely understood as a collection of polygons.

This understanding of TEK makes it a bargaining chip that can be used in negotiations with the state government or private companies. For example, under the 2002 agreement on forestry between the James Bay Cree and the Government of Québec, Cree hunters are allowed to identify up to $1 \%$ of the land for protection on cultural grounds (Government of Québec and Crees of Québec 2002). Any type of protection that would threaten the forest companies' capacity to produce wood would force the government to compensate these companies for lost volumes of timber. It could therefore be argued that a monetary value was attributed to the areas to be protected, at least indirectly.

For many scholars, to associate TEK with discrete entities to be protected or traded such as in the case reported above is problematic (e.g., Rundstrom 
1995, McGregor 1999, Stevenson 1999, Simpson 2001) because providing information about wildlife habitats or the location of sites of human occupation such as temporary hunting camps or portage trails fails to guide management practices in a direction that is truly compatible with aboriginal values and is not representative of the depth of the knowledge that First Nations possess about the land. Furthermore, this type of data acquisition has been considered problematic because the same scholars believe that TEK cannot be extracted from its holder and from the context in which it was created without losing part of its meaning (e.g., McGregor 1999, 2000, Simpson 2001, Gallagher 2003), especially if First Nations do not have control over how this knowledge is to be projected in reports, scholarly journals, or maps (Johnson 1992b, Kuhn and Duerden 1996, Stevenson 1996, Nadasdy 1999).

To address these concerns, a definition of TEK that accounts for more than the discrete, localized, and localizable data about the environment of which it is partly composed must be provided. Therefore, I use Usher's (2000:185) definition of TEK, which states that "TEK refers specifically to all types of knowledge about the environment derived from experience and traditions of a particular group of people" (my emphasis). What these types of knowledge are exactly is what I will identify in the next section, after a brief overview of the nomenclature attributed to what I refer to as TEK.

\section{The nomenclature of traditional ecological knowledge}

It is perhaps because TEK connects such varied dimensions as the type of knowledge, the identity of knowledge holders, and the process of knowledge acquisition that there exists a great variety of definitions and an extensive nomenclature for TEK. For some, this intimate knowledge can be labeled as "local" or "indigenous knowledge" to emphasize its very localness (e.g., Warren and Rajasekaran 1995, Antweiler 2004) because it is "embedded in its particular community, it is contextually bound, (...) and it requires a commitment to the local context" (Banuri and Apffel-Marglin 1993, as quoted in Agrawal 1995:418). The word indigenous is used by some specifically to point out that it refers to knowledge systems "unique to a particular community or ethnic group" (Warren and Pinkston 1998:158).
For others, the expression "traditional knowledge" is deemed more appropriate because it shows the ancient roots of "much of this knowledge" (Nickels 1999:8) and the idea that it is knowledge that is transmitted from one generation to the next (Hobson 1992, Brant Castellano 2000). However, this use of the word traditional is viewed by some (e.g., Stevenson 1996, 1999) as not empowering to people because it may be perceived as referring to a distant past, without illustrating the dynamical aspect of that knowledge and its current relevance. Aboriginals sometimes feel that "the term 'traditional' imposes a way of life on them that is shackled to the past and does not allow them to change" (Gombay 1995, as quoted in Stevenson 1996:280).

Conversely, First Nations themselves are sometimes tempted to use the word traditional, especially in the context of the negotiation of comanagement arrangements, specifically to root their knowledge in the past and give it the authority of difference in the face of state resource management, which claims to be supported by science. In the public eye, First Nations' legitimacy in negotiating for the co-management of the land partly lies in the existence of located ancestral traditions reproduced over time immemorial. If identities and cultures are in constant transformation and never fixed within time or space, this begs the question of how one is to approach negotiations when bearing in mind that the hegemonic social group involved in the negotiation process wishes to convey the message that if culture does transform over time or moves through space, it is no longer traditional and is therefore an invalid partner in the negotiation. This questioning refers to what Rose (1993) labeled as a paradoxical space situated both at the center and at the margins of power. As Hooks (1991, as quoted in Valentine 2001:149) states, "[Marginality is] a site one stays in, clings to even, because it nourishes one's capacity to resist." Different cultural traditions, from which emerged, for instance, particular land stewardship systems, have placed Canadian First Nations at the margins of Canadian society both economically and socially, whereas the recognition of that difference by both the First Nations and non-Natives authorizes the First Nations to negotiate co-management arrangements.

This discussion has implications for my analysis because it shows that if the three goals stated in the introduction, i.e., increased equity, increased efficiency of management decisions, and increased 
robustness of ecological management decisions, are to be reached, it becomes necessary to give more authority to traditional knowledge and involve it as complementary to scientific knowledge development. For the purposes of my analysis, I use the expression "traditional ecological knowledge" to emphasize the connection of traditional knowledge to ecological processes, as well as to emphasize its importance in the context of environmental comanagement.

\section{THE FACES OF TRADITIONAL ECOLOGICAL KNOWLEDGE}

Several authors have attempted to contrast the knowledge of the environment possessed by local aboriginal groups with the knowledge system used by the colonizer. Some (e.g., Cruikshank 1981, Stevenson 1996, Usher 2000) have broken down the types of knowledge elements into categories that, taken together, form the traditional ecological knowledge of a group. This is an attempt to understand how traditional ecological knowledge (TEK) could be an informative complement to science or how it could be involved in environmental management. Other authors have also identified categories of TEK, although in a less comprehensive or explicit manner.

In the following section, I present a synthesis of these typologies that are provided in the literature to identify as precisely as possible the ways in which TEK is understood. This synthesis was done with the goal of using TEK in co-management arrangements in a manner that comprehensively satisfies First Nations. It identifies six interconnected and mutually informing faces (Fig. 1) of TEK that are to be considered by partners in co-management to better identify areas of difference and convergence when attempting to bring two ways of thinking and knowing together. TEK forms a pentagon held together by the cosmological underpinning that gives meaning to the knowledge system. The three faces at the bottom are those that non-Natives would tend to understand to a greater extent. To have a complete picture of a TEK system, however, the pentagon needs to be rotated. Furthermore, the nature of what holds the pentagon together must be acknowledged. The framework that I present differs from those that have already been offered in the literature in that it acknowledges more clearly the upper faces of the pentagon (faces four, five, and six) and specifically identifies TEK as a vector for cultural identity. By being more detailed about the characterization of the upper three faces, the framework allows for better reflection on the most challenging aspects of TEK involvement in co-management arrangements.

\section{First face: factual observations, classifications, and system dynamics}

The most understood aspect of TEK is the body of factual, specific observations that TEK holders are capable of generating. It is also the body of knowledge that was first explored by nonaboriginal researchers through folk taxonomy studies. This face of TEK therefore consists of the recognition, naming, and classification of discrete components of the environment (Johnson 1992b, Mailhot 1993, Kuhn and Duerden 1996, Neis et al. 1999, Nickels 1999, Antweiler 2004). It is a set of both separate empirical observations and information, i.e., synthesized data (Wenzel 1999), such as facts about animals and their behavior and habitat, the anatomy of species, and animal abundance (Nakashima 1990, Freeman 1992, Mailhot 1993, Kuhn and Duerden 1996, Neis et al. 1999, Brant Castellano 2000, Huntington 2000, Turner et al. 2000, Simpson 2001, Nadasdy 2003b, Peters 2003, Wenzel 2004). This type of knowledge is also about understanding the interrelationships that occur among species, the connections within the biophysical environment, and the spatial distributions and historical trends of spatial and population patterns, allowing for the monitoring of ecosystem health indicators and the measurement of ecological changes, including climate (Freeman 1992, Johnson 1992a,b, Mailhot 1993, Ferguson and Messier 1997, Duerden and Kuhn 1998, Neis et al. 1999, Nickels 1999, Wenzel 1999). Thus, it is as much about understanding the dynamics of ecosystems as about the description of their components.

This type of empirical knowledge consists of a set of generalized observations conducted over a long period of time and reinforced by accounts of other TEK holders (Usher 2000). It is therefore personal knowledge, but it is enriched and validated through social life. It has been pointed out that it is linked to survival, i.e., it is an "appropriate" ecological knowledge (Berkes 1988), but that it can also emerge out of sheer curiosity (Johnson 1992b). 
Fig. 1. The six faces of traditional ecological knowledge.

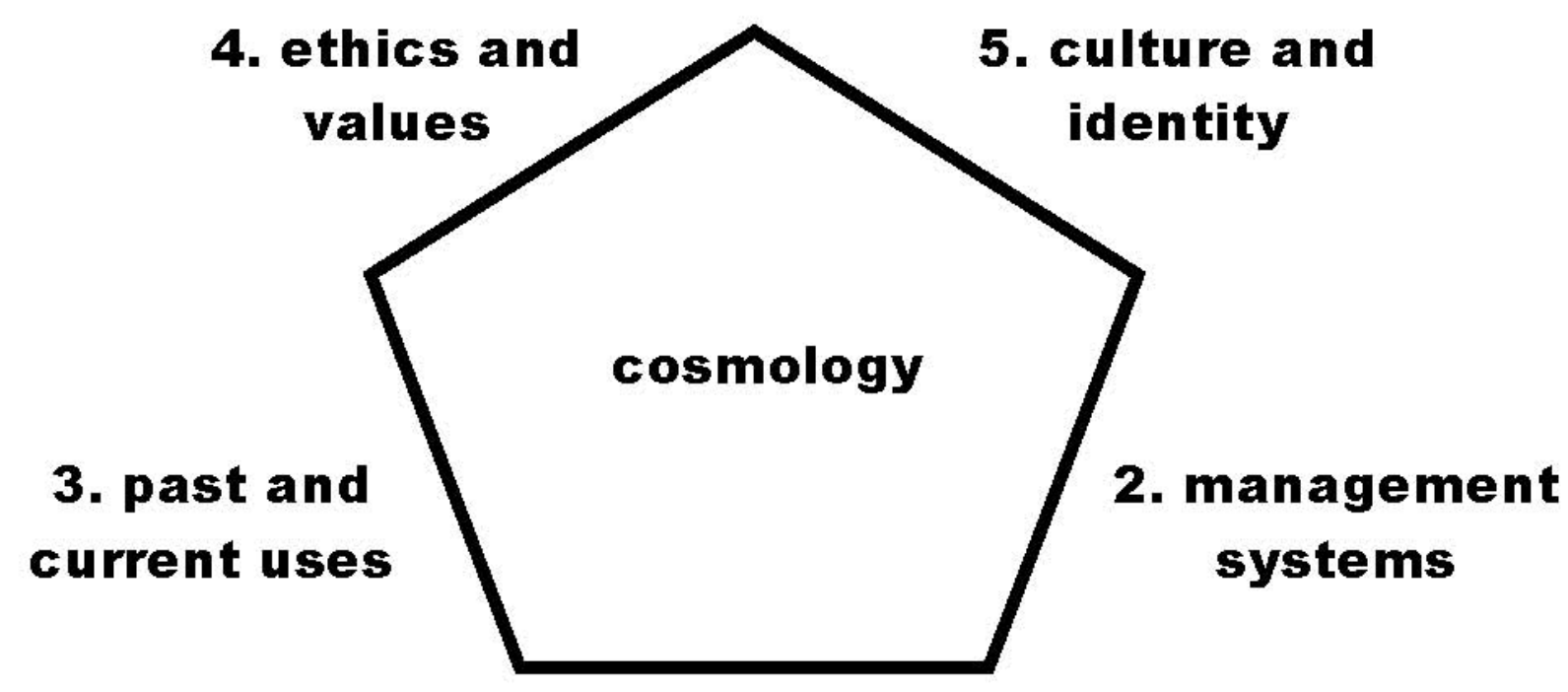

1. factual

observations

This is the face that is most compatible with the knowledge used by resource management bureaucrats (Berkes 1999, Nadasdy 2003a,b). It is a type of knowledge that is attractive to many because it may enhance scientific knowledge about the environment, but also provides additional information to databases while monitoring for environmental changes. This is seen as most useful in the context of environmental impact assessments (Stevenson 1996, Usher 2000), risk assessments (e. g., Nakashima 1990), and the management of species at risk (e.g., Kendrick 2003). It is therefore able to somewhat increase the participation of First Nations in decision-making processes by helping to identify, for instance, unforeseen and undesirable consequences of development projects. It provides First Nations with the opportunity to influence the direction of resource management actions.
However, as long as First Nations do not have more control over the final decisions being made in resource management and as long as they do not participate more in the managing of that information, factual TEK is open to being misinterpreted or discarded when it does not serve the particular interests of the state or private interests represented by the state. This lack of control over TEK and its interpretation has been pointed out by many Aboriginals as a source of great concern (e. g., McGregor 1999). The les TEKs or les milieux de vies to which I referred earlier exemplify problems that arise from a lack of information control by First Nations. When a forest company consults a hunting family regarding the land, it catalogs sites to be protected. However, once these data are integrated into the company's databases to generate logging models, the family loses control of the way in which the logging will actually be done, which may be 
very far removed from what the family had imagined. In Québec, for instance, whereas consultations with a generic Autochtones (Indigenous) category of actors are mandatory for forest planners, consensus on logging plans is by no means required (Government of Québec 2006). The next time the company has to plan, it may not even consider it useful to return to consult with the family because it already has its "TEK" in storage. These concerns about losing control of the interpretation of data are not helped by TEK research titles such as "Capturing Traditional Environmental Knowledge" (Johnson 1992b), "Taking Advantage of Indigenous Knowledge" (Veitayaki 2002), or "One Last Chance: Tapping Indigenous Knowledge (...)" (Thomas 2003). This focus on the utility and economic value of TEK has led indigenous peoples worldwide to construct arguments toward the recognition of fundamental rights to TEK, including a share of the monetary benefits obtained from the use of this knowledge (Mauro and Hardison 2000).

\section{Second face: management systems}

As mentioned earlier and discussed extensively in the literature, TEK largely serves the purpose of subsistence. Therefore, a major theme of research on TEK is that of resource management systems and how they are adapted to local environments. Thus, the second face of TEK refers to the strategies for ensuring the sustainable use of local natural resources such as pest management, resource conservation, multiple cropping patterns, and methods for estimating the state of resources (Berkes 1988, Gunn et al. 1988, Johnson 1992a,b, Gadgil et al. 1993, Mailhot 1993, Agrawal 1995, Kuhn and Duerden 1996, Ferguson and Messier 1997, Duerden and Kuhn 1998, Nadasdy 1999, Neis et al. 1999, Nickels 1999, Turner et al. 2000, Simpson 2001, Peters 2003, Antweiler 2004, Lewis and Sheppard 2005). This face acknowledges that TEK is a "complex web of practices" related to the knowledge of animals and their interrelationships (Nadasdy 1999:6) that adapts to change by developing appropriate and effective technologies (Johnson 1992b, Warren and Rajasekaran 1995, Wenzel 2004).

This face of TEK has been investigated in the North American context by academics through studies of management systems such as harvesting rotations in beaver trap-line systems (Feit 1978, Berkes 1998), controlled fires in the Yukon (Lewis 1989), and patterns of wild egg collection (Hunn et al. 2003). These studies have aimed at finding novel ways of managing the environment in a sustainable manner. This line of work is undertaken in the context of an increased realization that ecosystems are complex, that one-size-fits-all management policies are ill adapted to consider local specificities, and that adaptive processes are needed to cope with change (Holling and Meffe 1996, Gunderson 1999).

Some promising attempts have been made to implement flexible, locally based management systems, for instance, the implementation of model forests throughout Canada in which local aboriginal communities may be able to gain greater control of information management, forest practices, and the outcomes of management activities. An example of a model forest managed under aboriginal responsibility is that of Waswanipi on Québec Cree land (http://www.modelforest.net/cmfn/en/forests/ waswanipi/default.aspx). Further advances have been made recently in the updated Québec Forest Act, introduced in 2001, which has permitted the adaptation of forest management regulations to local needs, including those of First Nations, as long as these adaptations comply with provincial baseline standards (Government of Québec 2006).

\section{Third face: factual knowledge regarding past and current uses of the environment}

This third face of TEK highlights the time dimension of traditional knowledge while locating it precisely in space. It is knowledge of the past and current uses of the environment that is transmitted through oral history (Neis et al. 1999, Usher 2000, Peters 2003). It refers to the knowledge of historical patterns of land use and settlement, occupancy, and harvest levels (Duerden and Kuhn 1998, Wenzel 1999, Usher 2000). It also concerns the location of medicinal plants and cultural and historical sites (Mailhot 1993, Lewis and Sheppard 2005). Part of this dimension of TEK is life stories that are transmitted over generations through narratives that give a sense of family and community (Johnson 1992b, Cruikshank 1998, Callaway 2004).

This face of TEK is often revealed by Canadian First Nations in the context of land claims negotiations. The 1997 Supreme Court of Canada landmark decision in Delgamuukw vs. British Columbia gave wider authority to oral history (Joffe 2000). It is 
therefore now commonplace for First Nations to put historical sites such as burial places and occupancy patterns (e.g., Horvath et al. 2002), in addition to toponyms in local languages (Desbiens 2004, Charland 2005), on maps to reclaim lost geography and assert a historical aboriginal connection to the land. Although imperfect in its depiction of the depth of this connection, the exposure of this face of TEK is a compromise that First Nations make because it allows them to gain wider credibility within the western scientific paradigm while awaiting greater recognition of the authoritative value of their own knowledge systems.

Current land use is sometimes incorporated in landuse plans and is increasingly incorporated as multiple-use frameworks are proposed in different jurisdictions and as aboriginal rights over the use of natural resources are being awarded by court systems. However, First Nations are quite careful with the exposure of this type of knowledge because the lack of control over information can lead to misinterpretation and because benefits, for instance, from the sharing of medicinal plant locations, are not always distributed equitably.

The three faces that I have presented thus far are largely those with which non-Natives are most familiar. They are also those that are less problematic to consider in state resource management or co-management processes. The faces that I present next are much more abstract for non-Natives and potentially bear fundamental differences from the mainstream values that are encoded in Canadian institutions. They are therefore much more complex to involve fully in state resource management.

\section{Fourth face: ethics and values}

The fourth face of TEK relates to "value statements about how things should be" (Usher 2000:186). For Wenzel (2004), this face of TEK is the connection between the belief system (the fifth face) and the organization of facts and actions. Berkes (1988, 1999), in a more pragmatic approach, refers to an environmental ethics that keeps exploitive abilities in check. This face is the expression of values concerning correct attitudes, often identified as values of respect, to adopt toward nonhuman animals, the environment in general, and between humans (Johnson 1992b, Kuhn and Duerden 1996, Stevenson 1996, McGregor 1999, Nadasdy 1999,
Simpson 2001, Callaway 2004, Wenzel 2004, Lewis and Sheppard 2005).

This face of TEK is not currently well translated in state resource management. Policy documents often refer to the cultural rights of First Nations or rights to protect sacred spaces for the purpose of rituals, but these provisions do not allow for the full accommodation of alternative land ethics. First Nations have been increasingly vocal about their values in position papers and public meetings, but with very limited results. Catch-and-release fishing or trophy hunting are examples of incompatibility between state and aboriginal ethics that are not being addressed seriously. For instance, the Haida people of British Columbia have long opposed recreational bear hunting, which is considered disrespectful toward the animal (Council of the Haida Nation 2004). Since 1995, when the Council of the Haida Nation issued a formal request to ban recreational bear hunting on Haida Gwaii (Queen Charlotte Islands), the Haida have tried to encourage local outfitters to stop offering hunting opportunities to tourists and to provide bear-watching opportunities as an alternative (http://www.spruceroots.org/BearHunt/ BearHunt.html). This initiative has had limited effect because bear hunting still continues on Haida Gwaii, with the exception of Gwaii Haanas, which is a National Park located in the southern part of the archipelago (Burles et al. 2004, Process Management Team 2006).

\section{Fifth face: traditional ecological knowledge as a vector for cultural identity}

This face emphasizes the role of language and images of the past in giving life to culture. It has been argued that the land is at the heart of aboriginal cultures (First Nations of Québec and Labrador Sustainable Development Institute 2004) and that if the land "disappears," or transforms too much, cultures and peoples also disappear (Conseil de la Nation Atikamekw 2004). "Landscapes 'house' (...) stories, and the protection of these places is key to their long-term survival in Aboriginal culture" (Buggey 2004:17). This face of TEK understands the stories, values, and social relations that reside in places as contributing to the survival, reproduction, and evolution of aboriginal cultures and identities. It stresses the restorative benefits of cultural landscapes as places for spiritual renewal (Lewis and Sheppard 2005). 
Although European settlers first perceived North America as largely empty space, it was nevertheless full of meaning for First Nations. These meanings, spiritual or other, developed historically and are at the basis of what many have pointed to as being an aboriginal sense of place or feeling of home and of identity (Kuhn and Duerden 1996, Buggey 2004, Callaway 2004). It has been stated by many First Nations scholars and organizations (e.g., Conseil de la Nation Atikamekw 2004, First Nations of Québec and Labrador Sustainable Development Institute 2004) that there exist very strong connections among language and the use of meaningful toponyms, the consumption of country food, life on the land, identity, and cultural survival (e.g., Duerden and Kuhn 1998, Kulchyski 1998, Callaway 2004, Myers et al. 2005). Landscape features can act as points of reference for communicating tacit knowledge (Cruikshank 2005). It has further been noted that rapid transformation of the land can break historical connections with the past, thus changing its meaning for current generations. This has in turn eroded the sense of place, which is a central feature of aboriginal identities. Hydroelectric dams constitute an example of change that has a negative effect on aboriginal societies by flooding or draining places that are invested in meaning or by changing patterns in food consumption because of increases in methylmercury in fish (Dumont et al. 1998, Myers et al. 2005). Recently, attention has been directed toward the way that climate change or the presence of persistent pollutants in the Canadian Arctic is transforming the landscape from a place able to sustain the local communities socially and nutritionally to a place in which people now lack confidence in its ability to provide healthy sustenance (Berkes et al. 2005).

The need for meaningful landscapes pushes First Nations to express these connections among the state of the environment, language, the consumption of country food, life on the land, identity, and cultural survival while negotiating treaties or other co-management arrangements. By expressing this face, each First Nation affirms its identity as a coherent cultural whole located within the land for which it claims responsibility. The espression of this face strengthens First Nations' authority to negotiate co-management arrangements. Aboriginals refer to these connections when trying to force major shifts in environmental policy. In 2005, for instance, representatives of the Inuit people filed a petition to the Inter-American Commission on Human Rights, asserting that the United States, in refusing to sign international treaties to cut its greenhouse gas emissions, threatened Inuit rights to pursue their traditional lifestyles because these emissions change the climate and their living environment in the Arctic (Gertz 2005). In February 2007, the InterAmerican Commission on Human Rights agreed to hold a hearing on the matter (Earthjustice 2007). Similarly, the Cree Nation of James Bay alleged in the late 1990s that the Government of Québec was not being respectful of their treaty rights according to the James Bay and Northern Québec Agreement to pursue a way of life based in part on beaver trapping because the government was allowing too much logging to take place on Cree ancestral land (Grand Council of the Crees 1998). The landscape was changing too rapidly for the Cree to be able to sustain their culture. Through a court procedure and negotiation, the Cree and the Government of Québec settled the matter through a new agreement, the Peace of the Braves (Government of Québec and Crees of Québec 2002).

\section{Sixth face: cosmology}

The last identifiable face of TEK is a culturally based cosmology that is the foundation of the other faces and inseparable from them (Kuhn and Duerden 1996, Usher 2000). This face relates to the assumptions and beliefs about how things work (Neis et al. 1999, Nickels 1999). This is the worldview (Mailhot 1993, Duerden and Kuhn 1998, Turner et al. 2000, Antweiler 2004) that explains the way in which things are connected (Pierotti and Wildcat 2000) and gives the principles that regulate human-animal relations and the role of humans in the world (Berkes 1988, Mailhot 1993, Peters 2003). This dimension of TEK has been explored by many anthropologists and cultural ecologists in attempts to understand, for instance, how Cree (Berkes 1988) or Inuit (Wenzel 2004) peoples understand humannonhuman animal relationships and how these directly influence social relationships, obligations toward other community members, and management practices (Feit 1988, Johnson 1992b).

This dimension has been said to be akin to religion (e.g., Howard and Widdowson 1996, 1997). Others (e.g., Berkes and Henley 1997, Stevenson 1997) have counterargued that TEK is more of a philosophy than an ideology and that state resource management was, in any case, also founded on a certain philosophy that has been deeply influenced by a Christian values system. It has been argued (e. 
g., White 2006) that by separating the human being from the object being studied and by reducing the natural world to a collection of commodities traded through hunting or logging licences or land titles, bureaucrats have been working under the assumption that living beings are not equal, that humankind is a separate kingdom, and that nature is at the disposal of humans to be used as is deemed fit.

The appropriateness of opposing TEK and science as separate and different knowledge systems has therefore been under much criticism (Agrawal 1995). It has been argued that the way in which scientific narrative has been built is not so different from that of TEK. Furthermore, Watson-Verran and Turnbull (1995:116) argue that the "great divide in knowledge systems coincided with the great divide between societies that are powerful and those that are not" and that the difference between science and other knowledge systems has more to do with the power to impose a narrative as the truth through devices such as maps and books than with the processes of knowledge building. Consequently, Nadasdy (1999) proposes that research should focus on the power relations that have lead to the creation and imposition of knowledge systems. However, for the purposes of co-management, it is important to contrast alternative worldviews, difficult as it may be to accommodate fundamental and deeply rooted assumptions under a single management regime. However, emphasizing that worldviews are always shifting and in constant flux (Hubbard et al. 2002) suggests the potential for a more optimistic point of view, leading to the possibility of co-constructing new models of the world that would satisfy both parties.

The concept of the cultural landscape is by no means new (Johnston et al. 2000); however, the concept has never been fully integrated into the practice of resource management in Canada. Some attempts have been made, in Québec for instance, to develop the concept of forêt habitée (inhabited forest) and apply it to land-use planning (Bouthillier and Dionne 1995). This reflection, however, has never materialized in a major shift in forest management. I argue that it nevertheless deserves close attention, especially in the context of co-management. "To understand the northern landscape requires an understanding of the related cosmologies" (Buggey 2004:19). These are places that embody traditional narratives and spiritual meaning, as well as economic use (Buggey 2004). They are providers of both physical and spiritual reference and sustenance, as Lewis and Sheppard (2005) have noted. Consequently, propositions have been made (e.g., Karjala and Dewhurst 2003, Lewis and Sheppard 2005) to integrate aboriginal concerns at an earlier stage in land-use planning by projecting into the future what the land would look like under different management scenarios and by attempting to find scenarios that would match to a greater extent the idea of what the landscape should look like according to those who live there. Synchronizing logging planning and activities with beaver harvesting patterns or rotating protected areas to ensure that resources such as mature tree stands for bark collecting are always available are thought of as potential avenues for exploration.

\section{CHALLENGES AND OPPORTUNITIES}

Each of the six faces presents a number of challenges for the co-management of natural resources. I summarize these challenges, along with the key components of each of the faces (Table 1). The challenges of the first three faces have to do with the control over the data generated by traditional ecological knowledge (TEK) holders and the lack of confidence that non-Native people have in this data. Lack of trust among people is an obstacle to co-management (Olsson et al. 2004). It may well be somewhat challenging for bureaucrats, who are used to particular ways of producing and monitoring information, to accept information generated within a largely different knowledge system. Also, it may be challenging for central administrations to trust local organizations in developing new contextspecific management models.

The next three faces are even more complex to tackle in co-management arrangements because incompatible sets of values can be difficult to accommodate within a single management framework. Competing values in the general public are currently often addressed within liberal, multistakeholder policymaking processes in which the government attempts to strike a balance among competing values and interests. However, this type of framework is not a solution because First Nations organizations do not want to be considered as just another stakeholder (National Aboriginal Forestry Association 1995).

Dissimilar worldviews can also be very difficult to accommodate. Partners in the co-management process may mistrust alternative models of how 
Table 1. Characteristics of the six faces of traditional ecological knowledge (TEK).

\begin{tabular}{|c|c|c|}
\hline Face & Key components & Challenges \\
\hline $\begin{array}{l}\text { Factual obse- } \\
\text { rvations }\end{array}$ & $\begin{array}{c}\text { Empirical observations } \\
\text { Classifications } \\
\text { Naming of places } \\
\text { Descriptions of } \\
\text { ecosystem components } \\
\text { Understanding of } \\
\text { interconnections } \\
\text { Spatial and population } \\
\text { patterns } \\
\text { Ecosystems dynamics and } \\
\text { changes }\end{array}$ & $\begin{array}{c}\text { TEK open to misinterpretation } \\
\text { Equitable sharing of TEK monetary } \\
\text { benefits }\end{array}$ \\
\hline $\begin{array}{l}\text { Management } \\
\text { systems }\end{array}$ & $\begin{array}{l}\text { Practices adapted to } \\
\text { context } \\
\text { Methods for conservation } \\
\text { Methods for sustainable } \\
\text { resource use } \\
\text { Methods for adapting to } \\
\text { change } \\
\text { Appropriate and effective } \\
\text { technologies }\end{array}$ & $\begin{array}{l}\text { Diversification of management regimes } \\
\text { and methods } \\
\text { Transfer of responsibilities by central } \\
\text { administrations to develop context- } \\
\text { specific management models }\end{array}$ \\
\hline $\begin{array}{l}\text { Past and } \\
\text { current uses }\end{array}$ & $\begin{array}{c}\text { Land-use patterns } \\
\text { Occupancy } \\
\text { Harvest levels } \\
\text { History of the cultural } \\
\text { group } \\
\text { Location of cultural and } \\
\text { historical sites } \\
\text { Location of medicinal } \\
\text { plants }\end{array}$ & $\begin{array}{c}\text { Misinterpretation of oral history } \\
\text { Misinterpretation of occupancy patterns } \\
\text { Equitable sharing of TEK monetary } \\
\text { benefits }\end{array}$ \\
\hline
\end{tabular}

Ethics and Correct attitudes to adopt Values often incompatible with dominant values

Vector for cultural survival

Links life on the land, language, identity, and cultural survival

Cosmology discourse

Values not explicit in current management processes

Abstract dimension for nonaboriginals
Acceptance of aboriginal societies as vibrant and multifaceted Conciliation of multiple meanings

Mistrust of alternative narratives Structural and methodological problems for TEK holders in working with government bureaucrats
Opportunities

Enhancement of scientific knowledge

Added information for monitoring

of environmental changes

Criteria and indicators for environmental impact assessments and management of species at risk

Preparedness for social or ecological surprises

Decentralized, appropriate management regimes Novel sustainable approaches
Inspiration for new environmental ethics

Socially acceptable resource management systems

Rich cultural diversity

Restorative benefits of appropriate cultural landscapes

Reevaluation of long-lasting assumptions

Preparedness for social and ecological surprises 
things work. However, if partners put aside the initial assumptions that they have about how the world works to co-construct new models, as suggested by Bohm (1996), this could place aboriginals at risk to lose what sets them apart and gives them authority in participation in comanagement processes, i.e., their specific worldview and set of values.

As mentioned earlier, TEK requires a commitment to the local context. To keep TEK alive means spending a lot of time on the land. Therefore, a challenge that TEK poses to co-management is related to the logistical difficulty of reconciling the time that someone spends on the land with the timeconsuming commitment to interact with the comanagement board and to keep in touch with government bureaucrats and other stakeholders. This problem is not only a problem of time management, but a problem of the compatibility of methods of information acquisition, processing, and representation required by different knowledge systems.

Although these challenges are very real, the acknowledgment of the many faces of TEK also creates opportunities to enhance the comanagement of natural resources (Table 1). Collaborative processes are viewed as having the potential to enhance the robustness of ecological management decisions. Because knowledge about the complexity of ecosystems is incomplete within state bureaucracies and elsewhere, by involving TEK as a complete knowledge system with corresponding management systems that are coherent with local ecological and social contexts, it may be possible to be better prepared for unforeseen consequences of policy and management decisions made by outside bureaucrats. Also, local residents can provide early warning of environmental change (Olsson et al. 2004). Finally, TEK as a knowledge system allows for different perspectives when making sense of environmental complexity, as well as for novel ideas to cope with environmental change. To have available a multiplicity of varied locally based management systems and institutions could result in a wider set of experiences that could potentially be useful in coping with uncertainty and surprise.

In light of what has been argued regarding the cosmology of TEK, one main challenge for comanagement arrangements is to acknowledge that the knowledge systems of both local people and state bureaucrats are based on particular sets of values. From this perspective, the six faces framework could be applied to both of the knowledge systems interacting within the comanagement process to explicitly acknowledge the various points of view and find commonalities when co-constructing possible futures. This would also bring a richer cultural diversity to the discussion and possibly inspire new philosophies regarding the environment.

\section{CONCLUSION}

I reviewed the ways in which different observers of the Canadian resource management scene have conceptualized traditional ecological knowledge (TEK). This review has allowed for the identification of six faces of TEK, each of which is an important dimension to consider in the negotiation and design of co-management arrangements. I identified some of the attempts that have been made to consider each of these faces in current resource management regimes, as well as suggestions that have been made to involve First Nations more extensively in decision-making processes. I also pointed out some of the challenges posed by each face of TEK in the implementation of co-management arrangements. Different environmental ethics, values, and worldviews may be difficult to accommodate on the same land and within the same management system.

However, it is possible to envisage some long-term solutions toward the resolution of aboriginal claims. Co-management arrangements will have to be designed in such a way that First Nations communities can be involved from the initial stages of decision-making processes. This participation should not be limited to impact assessments for projects, but should also take place in the strategic planning phase when multiple futures are still possible. Involvement at a strategic level would allow for increased aboriginal control of TEK and a greater sense of aboriginal empowerment with regard to the events taking place on their own land while envisioning futures that are more attuned to their perception of how the land should be.

To achieve this, flexible legal frameworks need to be put in place to allow for co-management arrangements to change and adapt over time as trust builds between partners. These arrangements could find inspiration in adaptive environmental 
management methodologies and by focusing on learning about the systems being managed and about each of the partners' needs and values. Only with patience and flexibility will TEK find its rightful place and role in the cohabitation of the land.

Responses to this article can be read online at: http://www.ecologyandsociety.org/vol12/iss2/art34/responses/

\section{Acknowledgments:}

I gratefully acknowledge the contributions of Garry Peterson, Ciara Raudsepp-Hearne, Rowena Selby, and George Wenzel for their insightful and constructive comments on early drafts of the paper.

\section{LITERATURE CITED}

Agrawal, A. 1995. Dismantling the divide between indigenous and scientific knowledge. Development and Change 26:413-439.

Agrawal, A. 2003. Sustainable governance of common-pool resources: context, methods, and politics. Annual Review of Anthropology 32:243-262.

Antweiler, C. 2004. Local knowledge theory and methods: an urban model from Indonesia. Pages 1-34 in A. Bicker, P. Sillitoe, and J. Pottier, editors. Investigating local knowledge: new directions, new approaches. Ashgate, Aldershot, UK.

Berkes, F. 1988. Environmental philosophy of the Chisasibi Cree people of James Bay. Pages 7-21 in M. M. R. Freeman and L. N. Carbyn, editors. Traditional knowledge and renewable resource management in northern regions. Occasional publication number 23. Boreal Institute for Northern Studies, Edmonton, Canada.

Berkes, F. 1998. Indigenous knowledge and resource management systems in the Canadian subarctic. Pages 98-128 in F. Berkes and C. Folke, editors. Linking social and ecological systems: management practices and social mechanisms for building resilience. Cambridge University Press, Cambridge, UK.

Berkes, F. 1999. Sacred ecology: traditional ecological knowledge and resource management. Taylor and Francis, Philadelphia, Pennsylvania, USA.

Berkes, F., and T. Henley. 1997. Co-management and traditional knowledge: threat or opportunity? Policy Options 18(2):29-31.

Berkes, F., R. Huebert, H. Fast, M. Manseau, and A. Diduck, editors. 2005. Breaking ice: renewable resource and ocean management in the Canadian north. University of Calgary Press and Arctic Institute of North America, Calgary, Canada.

Bohm, D. 1996. On dialogue. Routledge, London, UK.

Bouthillier, L., and H. Dionne. 1995. La forêt à habiter: La notion de "forêt habitée" et ses critères de mise en ouvre. Final report to the Canadian Forest Service, Québec City, Canada.

Brant Castellano, M. 2000. Updating aboriginal traditions of knowledge. Pages 21-36 in G. J. Sefa Dei, B. L. Hall, and D. Goldin Rosenberg, editors. Indigenous knowledges in global contexts: multiple readings of our world. University of Toronto Press, Toronto, Canada.

Buggey, S. 2004 . An approach to aboriginal cultural landscapes in Canada. Pages 17-44 in I. Krupnik, R. Mason, and T. W. Horton, editors. Northern ethnographic landscapes: perspectives from circumpolar nations. Smithsonian Institution (Arctic Studies Center) and National Parks Service, Washington, D.C., USA.

Burles, D. W., A. G. Edie, and P. M. Bartier, editors. 2004. Native land mammals and amphibian of Haida Gwaii with management implications for Gwaii Haanas National Park Reserve and Haida Heritage Site. Technical reports in ecosystem science number 40. Parks Canada, Halifax, Canada.

Callaway, D. G. 2004. Landscapes of tradition, landscapes of resistance. Pages 177-201 in I. Krupnik, R. Mason, and T. Horton, editors. Northern ethnographic landscapes: perspectives from circumpolar nations. Smithsonian Institution (Arctic Studies Center) and National Parks Service, Washington, D.C., USA.

Cassidy, F. 1992. Aboriginal land claims in British Columbia. Pages 11-43 in K. Coates, editor. 
Aboriginal land claims in Canada: a regional perspective. Copp Clark Pitman, Toronto, Canada.

Charland, P. 2005. Définition et reconstitution de l'espace territorial du nord-est amériquain: La reconstruction de la carte du W8banaki par la toponymie abénakise au Québec. Dissertation. McGill University, Montréal, Canada.

Coates, K., editor. 1992. Aboriginal land claims in Canada: a regional perspective. Copp Clark Pitman, Toronto, Canada.

Conseil de la Nation Atikamekw. 2004. Cahier de propositions présenté dans le cadre des travaux de la Commission d'étude chargée d'examiner la gestion des forêts du domaine de l'État. Conseil de la Nation Atikamekw, La Tuque, Canada. Available online at: http://www.commission-foret.qc.ca/memoires/ doc 298 pro Attikamek.pdf.

Council of the Haida Nation. 2004. Haida land use vision. Council of the Haida Nation, Skidegate, Canada. Available online at: http://ilmbwww.gov.bc. ca/lup/lrmp/coast/qci/docs/HLUVpublic.pdf.

Cruikshank, J. 1981. Legend and landscape: convergence of oral and scientific traditions in the Yukon Territory. Arctic Anthropology 18(2):67-93.

Cruikshank, J. 1998. The social life of stories: narrative and knowledge in the Yukon Territory. University of British Columbia Press, Vancouver, Canada.

Cruikshank, J. 2005. Do glaciers listen? Local knowledge, colonial encounters, and social imagination. University of British Columbia Press, Vancouver, Canada.

Desbiens, C. 2004. Défricher l'espace de la nation: lieu, culture et développement économique à la baie James. Géographie et Cultures 49:87-104.

Duerden, F., and R. G. Kuhn. 1998. Scale, context, and application of traditional knowledge of the Canadian north. Polar Record 34(188):31-38.

Dumont, C., M. Girard, F. Bellavance, and F. Noël. 1998. Mercury levels in the Cree population of James Bay, Quebec, from 1988 to 1993/94. Canadian Medical Association Journal 158 (11):1439-1445. Available online at: http://www.cm aj.ca/cgi/reprint/158/11/1439.pdf.
Dupuis, R. 2001. Quel Canada pour les Autochtones? La fin de l'exclusion. Boréal, Montréal, Canada.

Earthjustice. 2007. Press release: Inter-American Commission on Human Rights to hold hearing on global warming. Earthjustice, Oakland, California, USA. Available online at: http://www.earthjustice. org/news/press/007/inter-american-commission-onhuman-rights-Hearing-on-Global-Warming.html.

Feit, H. A. 1978. Waswanipi realities and adaptations: resource management and cognitive structure. Dissertation. McGill University, Montréal, Canada.

Feit, H. 1988. Self-management and statemanagement: forms of knowing and managing northern wildlife. Pages 72-91 in M. M. R. Freeman and L. N. Carbyn, editors. Traditional knowledge and renewable resource management in northern regions. Occasional publication number 23. Boreal Institute for Northern Studies, Edmonton, Canada.

Ferguson, M. A. D., and F. Messier. 1997. Collection and analysis of traditional ecological knowledge about a population of Arctic tundra caribou. Arctic 50(1):17-28.

First Nations of Quebec and Labrador Sustainable Development Institute. 2004. Mémoire déposé à la Commission d'étude scientifique, publique et indépendante chargée d'examiner la gestion des forêts du domaine de l'état. Assembly of the First Nations of Québec and Labrador, Wendake, Canada.

Freeman, M. M. R. 1992. The nature and utility of traditional ecological knowledge. Northern Perpectives 20(1):9-12. Available online at: http:// www.carc.org/pubs/v20no1/utility.htm.

Gadgil, M., F. Berkes, and C. Folke. 1993. Indigenous knowledge for biodiversity conservation. Ambio 22(2-3):151-156.

Gallagher, C. 2003. Quit thinking like a scientist! Pages 183-190 in J. Oakes, R. Riewe, A. Edmunds, A. Dubois, and K. Wilde, editors. Native voices in research. Aboriginal Issues Press, Winnipeg, Canada.

Grand Council of the Crees. 1998. No agreement 
in forestry case: Crees and Quebec talks but no agreement signed to withdraw from court. Article number 31. Nemaska, Canada. Available online at: http://www.gcc.ca/archive/article.php?id=31.

Gertz, E. 2005. The snow must go on: Inuit fight climate change with human-rights claim against $U$. S. Grist [online] URL: http://www.grist.org/news/m aindish/2005/07/26/gertz-inuit.

Government of Canada. 2002. Land claims and self-government agreement among the Tlicho First Nation as represented by the Dogrib Treaty 11 Council and the Government of the Northwest Territories and the Government of Canada. Government of Canada, Ottawa, Canada. Available online at: http://www.ainc-inac.gc.ca/pr/agr/nwts/ tliagr e.html.

Government of Canada. 2005. Land claims agreement between the Inuit of Labrador and Her Majesty the Queen in Right of Newfoundland and Labrador and Her Majesty the Queen in Right of Canada. Government of Canada, Ottawa, Canada. Available online at: http://www.ainc-inac.gc.ca/pr/ agr/labi/index e.html.

Government of Québec. 2006. R.S.Q., c. F-4.1: Forest Act. Government of Québec, Québec City, Canada. Available online at: http://www2.publicati onsduquebec.gouv.qc.ca/dynamicSearch/telecharge. php?type $=2 \&$ file=/F 4 1/F4 1 A.html.

Government of Québec and Crees of Québec. 2002. Agreement concerning a new relationship (Paix des Braves) between le gouvernement du Québec and the Crees of Québec. Government of Québec, Québec City, Canada. Available online at: http://www.gcc.ca/pdf/LEG000000008.pdf.

Gunderson, L. 1999. Resilience, flexibility and adaptive management - - Antidotes for spurious certitudes? Conservation Ecology 3(1): 7. [online] URL: http://www.ecologyandsociety.org/vol3/iss1/ art7l.

Gunn, A., G. Arlooktoo, and D. Kaomayok. 1988. The contribution of the ecological knowledge of Inuit to wildlife management in the Northwest Territories. Pages 22-30 in M. M. R. Freeman and L. N. Carbyn, editors. Traditional knowledge and renewable resource management in northern regions. Occasional publication number 23. Boreal Institute for Northern Studies, Edmonton, Canada.
Hanna, S. S. 1998. Managing for human and ecological context in the Maine soft shell clam fishery. Pages 190-211 in F. Berkes and C. Folke, editors. Linking social and ecological systems: management practices and social mechanisms for building resilience. Cambridge University Press, Cambridge, UK.

Hobson, G. 1992. Traditional knowledge is science. Northern Perspectives 20(1):1. [online] URL: http: //www.carc.org/pubs/v20no1/science.htm.

Holling, C. S., and G. K. Meffe. 1996. Command and control and the pathology of natural resource management. Conservation Biology 10(2):328-337.

Horvath, S., L. MacKinnon, M. O. Dickerson, and M. M. Ross. 2002. The impact of the traditional land use and occupancy study on the Dene Tha' First Nation. Canadian Journal of Native Studies 22 (2):361-398.

Howard, A., and F. Widdowson. 1996. Traditional knowledge threatens environmental assessment. Policy Options 17(9):34-36.

Howard, A., and F. Widdowson. 1997. Traditional knowledge advocates weave a tangled web. Policy Options 18(3):46-48.

Hubbard, P., R. Kitchin, B. Bartley, and D. Fuller. 2002. Thinking geographically: space, theory, and contemporary human geography. Continuum, London, UK.

Hunn, E. S., D. R. Johnson, P. N. Russell, and T. F. Thornton. 2003. Huna Tlingit traditional environmental knowledge, conservation, and the conservation of a "wilderness" park. Current Anthropology 44(S5):S79-S103.

Huntington, H. P. 2000. Using traditional ecological knowledge in science: methods and applications. Ecological Applications 10(5):1270-1274.

Joffe, P. 2000. Assessing the Delgamuukw principles: national implications and potential effects in Quebec. McGill Law Journal 45:155-208.

Johnson, M. 1992a. Dene traditional knowledge. Northern Perspectives 20(1):2. [online] URL: http: //www.carc.org/pubs/v20no1/dene.htm. 
Johnson, M., editor. 1992b. Lore: capturing traditional environmental knowledge. Dene Cultural Institute and International Development Research Centre, Ottawa, Canada.

Johnston, R. J., D. Gregory, G. Pratt, and M. Watts, editors. 2000. The dictionary of human geography. Fourth edition. Blackwell, Oxford, UK.

Karjala, M. K., and S. M. Dewhurst. 2003. Including aboriginal issues in forest planning: a case study in central interior British Columbia, Canada. Landscape and Urban Planning 64(1-2):1-17.

Kearney, J. F. 1989. Co-management or cooptation?: The ambiguities of lobster fishery management in southwest Nova Scotia. Pages 85-102 in E. Pinkerton, editor. Co-operative management of local fisheries: new directions for improved management and community development. University of British Columbia Press, Vancouver, Canada.

Kendrick, A. 2003. Caribou co-management in northern Canada: fostering multiple ways of knowing. Pages 241-267 in F. Berkes, J. Colding, and C. Folke, editors. Navigating social-ecological systems: building resilience for complexity and change. Cambridge University Press, Cambridge, UK.

Kuhn, R. G., and F. Duerden. 1996. A review of traditional environmental knowledge: an interdisciplinary Canadian perspective. Culture 16(1):71-84.

Kulchyski, P. 1998. Bush/lands: some problems with defining the sacred. Pages 21-24 in J. Oakes, R. Riewe, K. Kinew, and E. Maloney, editors. Sacred lands: Aboriginal worldviews, claims, and conflicts. Canadian Circumpolar Institute, University of Alberta, Edmonton, Canada.

Lewis, H. T. 1989. A parable of fire: huntergatherers in Canada and Australia. Pages 7-20 in R. E. Johannes, editor. Traditional ecological knowledge: a collection of essays. IUCN, Gland, Switzerland.

Lewis, J. L., and S. R. J. Sheppard. 2005. Ancient values, new challenges: Indigenous spiritual perceptions of landscapes and forest management. Society and Natural Resources 18(10):907-920.

Mailhot, J. 1993. Traditional ecological knowledge: the diversity of knowledge systems and their study. Great whale environmental assesment. Background paper number 4. Montréal Great Whale Public Review Support Office, Montréal, Canada.

Mauro, F., and P. D. Hardison. 2000. Traditional knowledge of indigenous and local communities: international debate and policy initiatives. Ecological Applications 10(5):1263-1269.

McCay, B. J. 1996. Common and private concerns. Pages 111-126 in S. S. Hanna, C. Folke, and K.-G. Mäler, editors. Rights to nature: ecological, economic, cultural, and political principles of institutions for the environment. Island Press, Washington, D.C., USA.

McGregor, D. 1999. Indigenous knowledge in Canada: shifting paradigms and the influence of First Nations advocates. Pages 192-197 in T. S. Veeman, D. W. Smith, B. G. Purdy, F. J. Salkie, and G. A. Larkin, editors. Proceedings of the 1999 Sustainable Forest Management Network Conference: science and practice: sustaining the boreal forest (Edmonton, 1999). Sustainable Forest Management Network and University of Alberta, Edmonton, Canada.

McGregor, D. 2000. The state of traditional ecological knowledge research in Canada: a critique of current theory and practice. Pages $436-458$ in R. Laliberte, P. Settee, J. Waldram, R. Innes, B. Macdougall, L. McBain, and F. Barron, editors. Expressions in Canadian native studies. University of Saskatchewan Extension Press, Saskatoon, Canada.

Myers, H., H. Fast, M. K. Berkes, and F. Berkes. 2005. Feeding the family in times of change. Pages 23-45 in F. Berkes, R. Huebert, H. Fast, M. Manseau, and A. Diduck, editors. Breaking ice: renewable resource and ocean management in the Canadian north. University of Calgary Press and Arctic Institute of North America, Calgary, Canada.

Nadasdy, P. 1999. The politics of TEK: power and "integration" of knowledge. Arctic Anthropology 36 (1-2):1-18.

Nadasdy, P. 2003a. Hunters and bureaucrats: power, knowledge, and Aboriginal-state relations in the southwest Yukon. University of British Columbia Press, Vancouver, Canada. 
Nadasdy, P. 2003b. Reevaluating the comanagement success story. Arctic 56(4):367-380.

Nakashima, D. J. 1990. Les connaissances des autochtones appliquées aux études d'impact environnemental: les Inuits, les eiders et le pétrole de la baie d'Hudson. Conseil canadien de la recherche sur l'évaluation environnementale, Montréal, Canada.

National Aboriginal Forestry Association. 1995. Aboriginal participation in forest management: "not just another stakeholder." National Aboriginal Forestry Association, Ottawa, Canada.

Neis, B., L. F. Felt, R. L. Haedrich, and D. C. Schneider. 1999. An interdisciplinary method for collecting and integrating fishers' ecological knowledge into resource management. Pages 217-238 in D. Newell and R. E. Ommer, editors. Fishing places, fishing people: traditions and issues in Canadian small-scale fisheries. University of Toronto Press, Toronto, Canada.

Nickels, S. 1999. Importance of experiential context for understanding indigenous ecological knowledge: the Algonquins of Barriere Lake, Québec. Dissertation. McGill University, Montréal, Canada.

Notzke, C. 1995. A new perspective in aboriginal natural resource management: co-management. Geoforum 26(2):187-209.

Olsson, P., C. Folke, and F. Berkes. 2004. Adaptive comanagement for building resilience in socialecological systems. Environmental Management 34 (1):75-90.

Pagdee, A., Y.-S. Kim, and P. J. Daugherty. 2006. What makes community forest management successful: a meta-study from community forests throughout the world. Society and Natural Resources 19:33-52.

Pálsson, G. 1998. Learning by fishing: practical engagement and environmental concerns. Pages 48-66 in F. Berkes and C. Folke, editors. Linking social and ecological systems: management practices and social mechanisms for building resilience. Cambridge University Press, Cambridge, UK.

Persoon, G. A., and D. M. E. van Est. 2003. Comanagement of natural resources: the concept and aspects of implementation. Pages 1-24 in G. A. Persoon, D. M. E. van Est, and P. E. Sajise, editors. Co-management of natural resources in Asia: a comparative perspective. Man and nature in Asia series 7. Nordic Institute of Asian Studies, Copenhagen, Denmark.

Peters, E. J. 2003. Views of traditional ecological knowledge in co-management bodies in Nunavik, Québec. Polar Record 39(208):49-60.

Pierotti, R., and D. Wildcat. 2000. Traditional ecological knowledge: the third alternative (commentary). Ecological Applications 10(5):1333-1340.

Pinkerton, E., editor. 1989. Co-operative management of local fisheries: new directions for improved management and community development. University of British Columbia Press, Vancouver, Canada.

Process Management Team. 2006. Haida Gwaiil Queen Charlotte Islands land use plan recommendations report and addenda. Haida Gwaii/Queen Charlotte Islands Land Use Planning Process. Integrated Land Management Bureau, Victoria, Canada. Available online at: http://ilmbw ww.gov.bc.ca/lup/lrmp/coast/qci/docs/

fin LUP package Jan26-06.pdf.

Rose, G. 1993. Feminism and geography: the limits of geographical knowledge. University of Minnesota Press, Minneapolis, Minnesota, USA.

Rundstrom, R. A. 1995. GIS, indigenous peoples, and epistemological diversity. Cartography and Geographic Information Systems 22(1):45-57.

Schelhas, J., L. E. Buck, and C. C. Geisler. 2001. Introduction: the challenge of adaptive collaborative management. Pages xix-Xxxv in L. E. Buck, C. C. Geisler, J. Schelhas, and E. Wollenberg, editors. Biological diversity: balancing interests through adaptive collaborative management. CRC Press, Boca Raton, Florida, USA.

Scott, J. C. 1998. Seeing like a state: how certain schemes to improve the human condition have failed. Yale University Press, New Haven, Connecticut, USA.

Sheppard, S. R. J., and M. Meitner. 2005. Using multi-criteria analysis and visualisation for sustainable forest management planning with 
stakeholder groups. Forest Ecology and Management 207:171-187.

Simpson, L. 2001. Aboriginal peoples and knowledge: decolonizing our processes. Canadian Journal of Native Studies 21(1):137-148.

Stevenson, M. G. 1996. Indigenous knowledge in environmental assessment. Arctic 49(3): 278-291.

Stevenson, M. G. 1997. Ignorance and prejudice threaten environmental assessment. Policy Options 18(2):25-28.

Stevenson, M. G. 1999. What are we managing? Traditional systems of management and knowledge in cooperative and joint management. Pages 161-169 in T. S. Veeman, D. W. Smith, B. G. Purdy, F. J. Salkie, and G. A. Larkin, editors. Proceedings of the 1999 Sustainable Forest Management Network Conference: science and practice: sustaining the boreal forest (Edmonton, 1999). Sustainable Forest Management Network and University of Alberta, Edmonton, Canada.

Thomas, W. H. 2003. One last chance: tapping indigenous knowledge to produce sustainable conservation policies. Futures 35:989-998.

Turner, N. J., M. Boelscher Ignace, and R. Ignace. 2000. Traditional ecological knowledge and wisdom of aboriginal peoples in British Columbia. Ecological Applications 10(5):1275-1287.

Usher, P. J. 2000. Traditional ecological knowledge in environmental assessment and management. Arctic 53(2):183-193.

Valentine, G. 2001. Social geographies: space and society. Prentice Hall, New York, New York, USA.

Veitayaki, J. 2002. Taking advantage of indigenous knowledge: the Fiji case. International Social Science Journal 54(173):395-402.

Warren, D. M., and J. Pinkston. 1998. Indigenous African resource management of a tropical rainforest ecosystem: a case study of the Yoruba of Ara, Nigeria. Pages 158-189 in F. Berkes and C. Folke, editors. Linking social and ecological systems: management practices and social mechanisms for building resilience. Cambridge University Press, Cambridge, UK.
Warren, D. M., and B. Rajasekaran. 1995. Using indigenous knowledge for sustainable dryland management: a global perspective. Pages 193-209 in D. Stiles, editor. Social aspects of sustainable dryland management. Wiley and UNEP, Chichester, UK.

Watson-Verran, H., and D. Turnbull. 1995. Science and other indigenous knowledge systems. Pages 115-139 in S. Jasanoff, G. E. Markle, J. C. Petersen, and T. Pinch, editors. Handbook of science and technology studies. Revised edition. Sage Publications, Thousand Oaks, California, USA.

Wenzel, G. W. 1999. Traditional ecological knowledge and Inuit: reflections on TEK research and ethics. Arctic 52(2):113-124.

Wenzel, G. W. 2004. From TEK to IQ: Inuit Qaujimajatuqangit and Inuit cultural ecology. Arctic Anthropology 41(2):238-250.

White, G. 2006. Cultures in collision: traditional knowledge and Euro-Canadian governance processes in northern land-claim boards. Arctic 59:401-414. 